\title{
Analisis Kebijakan Penggunaan Tenaga Kerja Asing Di Indonesia (Dampak Dikeluarkannya Peraturan Presiden (Perpres) Nomor 20 Tahun 2018 Tentang Penggunaan Tenaga Kerja Asing)
}

\author{
Krista Yitawati \\ Dosen Ilmu Hukum, Universitas Merdeka Madiun, Jl. Serayu No.79, Madiun, 63133 \\ E-mail: krista@unmer-madiun.ac.id
}

\begin{abstract}
The consequences of globalization and liberalization of trade and investment, have an impact on the number of Foreign Workers (TKA) working in Indonesia and to support the national economy and the expansion of employment opportunities through increased investment, the government issued Presidential Regulation (Perpres) Number 20 of 2018 concerning the Use of Labor Foreign. For this reason, this study aims to analyze the policy of using foreign workers in Indonesia as a result of the issuance of Presidential Regulation (Perpres) Number 20 of 2018 concerning the Use of Foreign Workers. The research method that $I$ use is normative juridical. The results of this study, namely the use of foreign workers in Indonesia currently supported by the issuance of Presidential Regulation (Perpres) Number 20 of 2018 concerning the Use of Foreign Workers (TKA), will have a good impact on the development of investment from abroad to Indonesia. Because basically this Presidential Regulation aims to simplify the procedure for using foreign workers to increase investment, not to facilitate the requirements of foreign workers entering Indonesia. The more investors or investors investing in Indonesia, the more new jobs that can be opened.

Keywords : Policies; Foreign Workers; Investment.
\end{abstract}

Abstrak

Konsekuensi dari globalisasi dan liberalisasi perdagangan dan investasi, berdampak pada jumlah Tenaga Kerja Asing (TKA) yang bekerja di Indonesia dan untuk mendukung perekonomian nasional serta perluasan kesempatan kerja melalui peningkatan investasi, pemerintah mengeluarkan Peraturan Presiden (Perpres) Nomor 20 Tahun 2018 tentang Penggunaan Tenaga Kerja Asing. Untuk itu, penelitian ini bertujuan untuk menganalisis kebijakan penggunaan tenaga kerja asing di Indonesia sebagai dampak dari dikeluarkannya Peraturan Presiden (Perpres) Nomor 20 Tahun 2018 Tentang Penggunaan Tenaga Kerja Asing . Metode penelitian yang penulis gunakan adalah yuridis normatif. Hasil dari penelitian ini yaitu penggunaan TKA diIndonesia saat ini yang didukung dengan dikeluarkannya Peraturan Presiden (Perpres) Nomor 20 Tahun 2018 tentang Penggunaan Tenaga Kerja Asing (TKA), akan berdampak baik untuk perkembangan investasi dari luar negeri ke Indonesia. Karena pada dasarnya Perpres ini bertujuan untuk mempermudah prosedur penggunaan TKA untuk meningkatkan investasi, bukan untuk mempermudah persyaratan TKA masuk ke Indonesia. Semakin banyak investor atau pemodal yang berinvestasi di Indonesia maka semakin banyak pula lapangan kerja baru yang bisa dibuka.

Kata Kunci : Kebijakan, Tenaga Kerja Asing, Investasi.

\section{A. PENDAHULUAN}

\section{Latar Belakang}

Pembangunan nasional sebagai pengamalan pancasila dan pelaksanaan Undang-Undang Dasar 1945, diarahkan pada peningkatan harkat dan martabat serta kemampuan manusia, juga kepercayaan pada diri sendiri dalam rangka mewujudkan masyarakat sejahtera, adil dan makmur baik materiil maupun spiritual, dimana salah satu bagian yang tidak terpisahkan adalah pembangunan sektor ketenagakerjaan sebagai bagian dari upaya pembangunan sumber daya manusia.

Peran serta pekerja dalam pembangunan semakin meningkat dalam perkembangan pembangunan nasional di seluruh tanah air dan semakin meningkatnya penggunaan teknologi di berbagai sektor kegiatan usaha, dapat mengakibatkan semakin tinggi resiko dan tantangan yang dihadapi.

Pembangunan nasional yang penuh tantangan dan persaingan akan dipengaruhi oleh kualitas sumber daya manusia yang menguasai ilmu pengetahuan dan teknologi. Sumber daya manusia yang berkualitas akan menjadi penentu dan aset yang paling berharga dalam era globalisasi saat ini.

Perkembangan globalisasi identik dengan proses liberalisasi ekonomi dunia, menjadikan dunia menjadi satu pasar yang bebas dalam melakukan transaksi jual dan beli. Globalisasi juga menghendaki bebasnya pergerakan tenaga kerja ( pree 


\section{Website : http://yustisia.unmermadiun.ac.id/index.php/yustisia}

personal movement ) yang akan mengisi lapangan kerja melewati batas wilayahterritorial negaranya. ${ }^{1}$ Keadaan yang demikian dapat disebut sebagai liberalisasi pasar kerja. ${ }^{2}$

Konsekuensi dari globalisasi dan liberalisasi perdagangan dan investasi, seperti penanaman modal asing secara langsung, berdampak pada jumlah TKA yang bekerja di Indonesia yang cenderung mengalami peningkatan dari waktu ke waktu. Apalagi Indonesia sebagai bagian dari komunitas dunia seperti World Trade Organisation (selanjutnya disebut WTO), Masyarakat Ekonomi Asean (MEA), Asean Free Trade Area (AFTA) dan Asia-Pacific Economic Cooperation (APEC) semakin memperbesar peluang masuknya TKA ke Indonesia.

Kebutuhan perangkat hukum khususnya di bidang ketenagakerjaan yaitu TKA perlu mendapatkan perhatian, karena keberadaan TKA yang bekerja di Indonesia sebagai bagian dari TKI yang juga harus mendapatkan perlindungan berdasarkan pada peraturan ketenagakerjaan Indonesia, di sisi lain pengembangan peningkatan keterampilan pekerja Indonesia perlu ditingkatkan untuk dapat berkompetisi yang sesuai dengan kebutuhan Masyarakat Ekonomi Asean, dan yang terlebih tidak kalah pentingnya adalah peran dari Dinas Tenaga Kerja dan Transmigrasi dalam hal ini peran pegawai pengawasan terhadap TKA yang bekerja di Indonesia. ${ }^{3}$

Kekhawatiran juga muncul dari kalangan pekerja/buruh terutama terhadap kualitas sumber daya pekerja yang berdampak pada kesempatan kerja, perlu disadari bahwa pendidikan pekerja Indonesia masih jauh dari keterampilan pendidikan TKA. ${ }^{4}$ Peraturan terkait TKA yang terbaru di tahun 2018 ini adalah Peraturan Presiden Nomor 20 Tahun 2018 tentang Penggunaan Tenaga Kerja Asing. Perpres ini dikeluarkan dengan pertimbangan untuk mendukung perekonomian nasional dan perluasan kesempatan kerja melalui peningkatan investasi, pemerintah memandang perlu pengaturan kembali perizinan penggunaan tenaga kerja asing. Namun dikeluarkan perpres ini menimbulkan pro dan kontra dimasyarakat.

\section{Rumusan Masalah}

Berdasarkan latar belakang di atas, maka penulis tertarik untuk menganalis mengenai kebijakan penggunaan tenaga kerja asing di Indonesia terkait dengan adanya pro dan kontra pada Peraturan Presiden Nomor 20 Tahun 2018 tentang Penggunaan Tenaga Kerja Asing ini.

\section{Metode Penelitian}

Metode penelitian yang akan dilakukan dalam mengkaji penelitian ini yang merupakan metode penelitian hukum normatif yaitu untuk menemukan hukum konkret yang sesuai untuk diterapkan guna menyelesaikan suatu permasalahan hukum tertentu. ${ }^{5}$ Yaitu untuk dapat memperoleh bahan hukum guna mengetahui dan menganalisis permasalahan yang timbul terkait kebijakan penggunaan Tenaga Kerja Asing. Dalam penelitian ini, pendekatan yang digunakan adalah pendekatan undang-undang (statute approach) dan pendekatan konseptual (conceptual approach).

Pendekatan undang-undang (statute approach) dilakukan dengan menelaah semua undang-undang dan regulasi yang bersangkut paut dengan isu hukum yang sedang ditangani. ${ }^{6}$ Fakta yang ada dikaitkan dengan peraturan perundang-undangan yang mengaturnya dan yang masih berlaku. Undang-undang dan regulasi yang digunakan dalam penelitian ini adalah Undang-Undang Nomor 13 Tahun 2003 tentang Ketenagakerjaan dan Peraturan Presiden Nomor 20 Tahun 2018 tentang Penggunaan Tenaga Kerja Asing. Setelah metode pendekatan undang-undang (statute approach), pendekatan yang digunakan selanjutnya adalah pendekatan konseptual (conceptual approach). Pendekatan konseptual (conceptual approach) beranjak dari pandangan-pandangan dan doktrin-doktrin yang berkembang di dalam ilmu hukum. ${ }^{7}$ Dalam penulisan ini, pendekatan konseptual (conceptual approach) digunakan adalah pandangan-pandangan dan doktrin-doktrin yang terkait dengan permasalahan Tenaga kerja Asing.

Untuk memecahkan rumusan masalah dalam penelitian ini, diperlukan adanya sumber-sumber penelitian. Sumber-sumber tersebut dapat dibedakan menjadi 2 (dua), yaitu bahan-bahan hukum primer dan bahan-bahan

\footnotetext{
${ }^{1}$ Agusmidah, 2011, Dilematika Hukum Ketenagakerjaan, Tinjauan Politik Hukum, buku II, Jakarta: PT.Sofmedia, h. 349.

${ }^{2}$ Agusmidah, Dilematika Hukum Ketenagakerjaan, Tinjauan Politik Hukum, buku II, Jakarta: PT.Sofmedia, 2011. h. 350.

${ }^{3}$ Suhandi. Pengaturan Ketenagakerjaan Terhadap Tenaga Kerja Asing Dalam Pelaksanaan Masyarakat Ekonomi Asean Di Indonesia, Jurnal Fakultas Hukum Universitas Wijaya Kusuma Surabaya, Perspektif Volume XXI No. 2 Tahun 2016 Edisi Mei, hlm 136

${ }_{5}^{4}$ Agusmidah, Dilematika Hukum, h. 151

${ }^{5}$ Rony Hanintyo Soemitro, 1982, Metodologi Penelitian Hukum, Ghalia Indonesia, Jakarta, hlm. 10

${ }^{6}$ Peter Mahmud Marzuki, 2007, Penelitian Hukum, Kencana Prenada Media Group, Jakarta, h. 93.

${ }^{7}$ Ibid., h. 95.
} 
Website : http://yustisia.unmermadiun.ac.id/index.php/yustisia

hukum sekunder. Bahan hukum primer merupakan bahan hukum yang bersifat autoritatif, artinya mempunyai kekuasaan. Bahan-bahan hukum primer terdiri dari perundang-undangan, catatan-catatan resmi atau risalah dalam pembuatan perundang-undangan, dan putusan-putusan hakim. Sumber bahan hukum primer dalam penelitian ini adalah Undang-Undang Nomor 13 Thaun 2003 tentang Ketenagakerjaan dan Peraturan Presiden Nomor 20 Tahun 2018 tentang Penggunaan Tenaga Kerja Asing.

Selain menggunakan bahan-bahan hukum primer, penelitian ini juga menggunakan bahan-bahan hukum sekunder. Bahan-bahan hukum sekunder berupa semua publikasi tentang hukum yang bukan merupakan dokumen-dokumen resmi. Bahan-bahan hukum sekunder yang digunakan dalam penelitian ini, antara lain bukubuku literatur, kamus hukum, jurnal-jurnal hukum, serta komentar-komentar para ahli atas putusan pengadilan.

Prosedur pengumpulan bahan hukum untuk penelitian ini dilakukan dengan cara inventarisasi dan kategorisasi. Sumber bahan hukum yang telah dikumpulkan kemudian dikategorikan. Selanjutnya, sumber bahan hukum yang telah dikumpulkan dan dikategorikan tersebut berdasarkan cara studi kepustakaan dilakukan dengan mempelajari pendapat para ahli yang tertuang dalam buku-buku literatur, kamus hukum, jurnal-jurnal hukum, dan majalah hukum. Apabila berkaitan dengan rumusan masalah yang sedang dibahas dapat dilakukan pengutipan jika diperlukan. Dalam penelitian ini, semua bahan hukum, baik sumber bahan hukum primer maupun sumber bahan hukum sekunder, dianalisis dengan menggunakan metode deduktif, yaitu metode yang menganalisis ketentuan-ketentuan hukum sebagai suatu hal yang umum kemudian ditarik kesimpulan yang bersifat khusus.

\section{B. PEMBAHASAN}

Menurut Undang-undang Nomor 13 Tahun 2013 tentang Ketenagakerjaan, yang dimaksud dengan ketenagakerjaan adalah segala hal yang berhubungan dengan tenaga kerja pada waktu sebelum, selama dan sesudah masa kerja. Jadi hukum ketenagakerjaan dapat diartikan sebagai peraturan-peraturan yang mengatur tenaga kerja pada waktu sebelum, selama dan sesudah masa kerja. Namun Pengertian pekerjaan dan seperti apa yang harus dikerjakan oleh pekerja tidak dijumpai dalam peraturan ketenagakerjaan, Namun Imam Soepomo secara teoritis mengemukakan pekerjaan adalah perbuatan untuk kepentingan pengusaha, baik langsung maupun tidak langsung dan bertujuan secara terus menerus untuk meningkatkan produksi, baik kuantitas maupun kualitasnya. $^{8}$

Sedangkan pengertian tenaga kerja dalam Pasal 1 ayat (2) Undang-Undang Nomor 13 Tahun 2003 tentang Ketenagakerjaan menyatakan :

"Tenaga kerja adalah setiap orang yang mampu melakukan pekerjaan guna menghasilkan barang dan/atau jasa baik untuk memenuhi kebutuhan sendiri maupun untuk masyarakat."

Tenaga Kerja Asing (TKA) adalah tiap orang bukan warga Negara Indonesia yang mampu melakukan pekerjaan, baik di dalam maupun di luar hubungan kerja, guna menghasilkan jasa atau barang untuk memenuhi kebutuhan masyarakat. ${ }^{9}$ Pengertian tenaga kerja asing ditinjau dari segi undang-undang (pengertian otentik), yang dimana pada Pasal 1 angka (13) Undang-Undang Nomor 13 Tahun 2013 tentang Ketenagakerjaan dinyatakan bahwa: "Tenaga kerja asing adalah warga negara asing pemegang visa dengan maksud bekerja di wilayah Indonesia". ${ }^{10}$ Ada empat macam visa yang diakui dalam Undang-Undang Nomor 6 Tahun 2011 tentang Keimigrasian, yakni visa diplomatik, visa dinas, visa kunjungan, dan visa tinggal terbatas. Visa untuk pekerja masuk dalam lingkup visa tinggal terbatas. ${ }^{11}$

Tujuan penggunaan TKA tersebut adalah untuk memenuhi kebutuhan tenaga kerja yang terampil dan professional pada bidang tertentu yang belum dapat diduduki oleh tenaga kerja lokal serta sebagai tahapan dalam mempercepat proses pembangunan nasional maupun daerah dengan jalan mempercepat alih ilmu pengetahuan dan teknologi dan meningkatkan investasi asing terhadap kehadiran TKA sebagai penunjang pembangunan di Indonesia walaupun pada kenyataannya perusahaan-perusahaan yang ada di Indonesia baik itu perusahaan perusahaan swasta asing ataupun swasta nasional wajib menggunakan tenaga ahli bangsa Indonesia sendiri. $^{12}$

Penggunaan TKA mempunyai kelebihan dan kekurangan tersendiri, kelebihan diantaranya yaitu:

a. Dengan adanyaTKA, perusahaan yang sebelumnya hampir mati, setelah adanya TKA dapat berjalan lancar sehingga dapat memberi lapangan kerja bagi TKI;

b. TKI memperoleh kesempatan pendidikan dan pelatihan dari TKA;

\footnotetext{
${ }^{8}$ Imam Soepomo dalam Zaeny Asyhadie, 2013, Hukum Ketenagakerjaan Bidang Hubungan Kerja, Jakarta: Raja Grafindo Persada, hlm 69

${ }^{9}$ Abdul Khakim, 2009, Dasar-Dasar Hukum Ketenagakerjaan Indonesia, Bandung: Citra Aditya Bakti, hlm 27

${ }^{10}$ Ibid

${ }^{11}$ http://businesslaw.binus.ac.id/2017/01/29/tenaga-kerja-asing/diakses tanggal 18 Oktober 2018 Pukul 18.35 WIB.

${ }^{12}$ HR Abdussalam,2008 ,Hukum Ketenagakerjaan, Jakarta: Restu Agung, hlm 322.
} 
Website : http://yustisia.unmermadiun.ac.id/index.php/yustisia

c. TKI dapat mengambil banyak contoh cara kerja TKA yang teliti, disiplin dan menghargai waktu kerja;

d. Dengan adanya TKA, lama kelamaan dapat mentransfer teknologi dan ilmu pengetahuan yang dimiliki TKA dengan mula-mula mereka dapat menduduki jabatan terpenting dalam perusahaan, kemudian ilmu TKA dapat dialihkan dan secara perlahan jabatan tersebut berangsur-angsur dapat diisi atau digantikan oleh TKI. ${ }^{13}$

Pengaturan penggunaan TKA diatur dalam berbagai peraturan perundang-undangan di Indonesia, salah satu diantaranya adalah Undang-Undang Nomor 13 Tahun 2003 tentang Ketenagakerjaan. Penggunaan TKA diatur dari Pasal 42 sampai 49 Undang-Undang Nomor 13 Tahun 2003 tentang Ketenagakerjaan. Pasal 42 Undang-Undang Nomor 13 Tahun 2003 tentang Ketenagakerjaan, menyatakan :

a. Setiap pemberi kerja yang mempekerjakan tenaga kerja asing wajib memiliki izin tertulis dari Menteri atau pejabat yang ditunjuk.

b. Pemberi kerja orang perseorangan dilarang mempekerjakan tenaga kerja asing.

c. Kewajiban memiliki izin sebagaimana dimaksud dalam ayat (1), tidak berlaku bagi perwakilan negara asing yang mempergunakan tenaga kerja asing sebagai pegawai diplomatik dan konsuler.

d. Tenaga kerja asing dapat dipekerjakan di Indonesia hanya dalam hubungan kerja untuk jabatan tertentu dan waktu tertentu.

e. Ketentuan mengenai jabatan tertentu dan waktu tertentu sebagaimana dimaksud dalam ayat (4) ditetapkan dengan Keputusan Menteri.

f. Tenaga kerja asing sebagaimana dimaksud dalam ayat (4) yang masa kerjanya habis dan tidak dapat di perpanjang dapat digantikan oleh tenaga kerja asing lainnya. ${ }^{14}$

Undang-Undang Nomor 13 Tahun 2003 tentang Ketenagakerjaan mulai dari Pasal (42) sampai Pasal (49) mengatur mengenai Penempatan TKA yang diwajibkan memiliki Izin Mempekerjakan Tenaga Asing (IKTA). Proses mendapatkan IKTA menganut asas sponsorship yang artinya penggunaan tenaga asing adalah atas permintaan perusahaan, ini berarti tenaga asing tidak dapat bekerja mandiri. Penggunaan tenaga asing juga diatur harus bermanfaat untuk pertumbuhan ekonomi nasional, membantu memperluas kesempatan kerja, menganut sistem keseimbangan pendapatan dan program alih teknologi. Tenaga Kerja Asing (TKA), yang akan bekerja di Indonesia diperuntukkan pada jabatan-jabatan yang belum dapat diisi oleh TKI.

Pengaturan-pengaturan itu masih dirasa belum melindungi TKI, karena pelaksanaan ketentuan yang belum tepat juga kebebasan yang sangat luas yang diberikan kepada TKA dalam mengisi jabatan- jabatan yang strategis. Selain itu, pemberi kerja TKA wajib menunjuk tenaga kerja warga negara Indonesia sebagai tenaga pendamping tenaga kerja asing yang dipekerjakan untuk alih teknologi dan alih keahlian dari TKA dan melaksanakan pendidikan dan pelatihan kerja bagi TKI yang sesuai dengan kualifikasi jabatan yang diduduki oleh TKA sebagaimana diatur dalam Pasal 45 butir a dan b Undang-Undang Nomor 13 Tahun 2003 tentang Ketenagakerjaan. Selanjutnya, pemberi kerja yang memperkerjakan TKA tersebut wajib memulangkan TKA ke negara asalnya setelah hubungan kerjanya berakhir sebagaimana diatur dalam 48 Undang-Undang Nomor 13 Tahun 2003 tentang Ketenagakerjaan.

Tujuan pengaturan mengenai TKA ditinjau dari aspek hukum ketenagakerjaan pada dasarnya adalah untuk menjamin dan memberi kesempatan kerja yang layak bagi warga negara Indonesia di berbagai lapangan dan level. ${ }^{15}$ Karenanya dalam mempekerjakan TKA dilakukan melalui mekanisme dan prosedur yang ketat dimulai dengan seleksi dan prosedur perizinan serta pengawasan. ${ }^{16}$

Pada prinsipnya, filosofi penggunaan TKA di Indonesia adalah mereka yang dibutuhkan dalam dua hal sebagai berikut :

a. Tenaga kerja asing yang membawa modal (sebagai investor); dan

b. Tenaga kerja asing yang membawa skill (keahlian) dalam rangka transfer teknologi ataupun keterampilan.

Dan guna untuk untuk mendukung perekonomian nasional dan perluasan kesempatan kerja melalui peningkatan investasi, pemerintah memandang perlu pengaturan kembali perizinan penggunaan tenaga kerja asing. Atas dasar pertimbangan tersebut, pada 26 Maret 2018, Presiden Joko Widodo telah menandatangani Peraturan Presiden (Perpres) Nomor 20 Tahun 2018 tentang Penggunaan Tenaga Kerja Asing. Namun dikeluarkan perpres ini telah menimbulkan pro dan kontra di tengah masyarakat. Pihak-pihak yang pro menganggap perpres tersebut bakal memberikan investasi lebih banyak dari luar negeri ke dalam negeri.

\footnotetext{
${ }^{13}$ Sri Badi Purwaningsih, 2005, "Pembatasan Penggunaan Tenaga Kerja Asing Pada Perusahaan-Perusahaan PMA di Jawa Tengah", Tesis Magister Hukum, Semarang: Universitas Diponegoro, hlm. 153.

${ }^{14}$ Siti Rahmawati dan Ni Luh Gede Astariyani, , 2016, Akibat Hukum Terhadap Penggunaan Tenaga Kerja Asing Ilegal menurut Undang-Undang Nomor 13 Tahun 2003 Tentang Ketenagakerjaan, Karya Ilmiah, Fakultas Hukum Universitas Udayana, hlm 1.

${ }^{15}$ Agusmidah, Loc.Cit

${ }^{16}$ Ibid
} 
Website : http://yustisia.unmermadiun.ac.id/index.php/yustisia

Namun, pihak-pihak yang kontra justru merasa perpres tersebut bakal membuat arus kedatangan pekerja asing ke dalam negeri semakin deras.

Berdasarkan analisa penulis terkait penggunaan TKA di Indonesia saat ini yang didukung dengan dikeluarkan perpres tentang pengaturan TKA ini akan baik untuk perkembangan investasi dari luar negeri ke Indonesia. Filosofinya perpres ini hanya ingin mempermudah prosedur untuk meningkatkan investasi, bukan untuk mempermudah persyaratan TKA masuk ke Indonesia. Semakin banyak investor atau pemodal yang berinvestasi di Indonesia maka semakin banyak pula lapangan kerja baru yang bisa dibuka. Melalui perpres tersebut, pemerintah ingin menerapkan kemudahan pemberian visa bagi tenaga ahli asing guna proses transfer pengetahuan dan teknologi bagi tenaga kerja lokal. Walaupun ada perpres tersebut, pemerintah tetap secara ketat menyeleksi TKA yang masuk ke Indonesia. Kualifikasi TKA yang boleh masuk ke Indonesia tidak dilonggarkan, hanya untuk menyederhanakan perizinan di Indonesia yang berbelit-belit sehingga kerap memakan biaya tinggi dan menimbulkan pungutan liar (pungli).

Dalam Perpres ini disebutkan, penggunaan Tenaga Kerja Asing (TKA) dilakukan oleh Pemberi Kerja TKA dalam hubungan kerja untuk jabatan tertentu dan waktu tertentu, yang dilakukan dengan memperhatikan kondisi pasar tenaga kerja dalam negeri. Setiap Pemberi Kerja TKA, menurut Perpres ini, wajib mengutamakan penggunaan tenaga kerja Indonesia pada semua jenis jabatan yang tersedia. Dalam hal jabatan sebagaimana dimaksud belum dapat diduduki oleh tenaga kerja Indonesia, jabatan tersebut dapat diduduki oleh TKA. Dalam Pasal 4 ayat $(1,2)$ juga disebutkan TKA dilarang menduduki jabatan yang mengurusi personalia dan/atau jabatan tertentu yang ditetapkan oleh Menteri. Perpres ini juga menegaskan, bahwa Pemberi Kerja TKA pada sektor tertentu dapat mempekerjakan TKA yang sedang dipekerjakan oleh Pemberi Kerja TKA yang lain dalam jabatan yang sama, paling lama sampai dengan berakhirnya masa kerja TKA sebagaimana kontrak kerja TKA dengan Pemberi Kerja TKA pertama.

Perpres ini juga memuat bahwa setiap Pemberi Kerja TKA yang menggunakan TKA harus memiliki RPTKA (Rencana Penggunaan Tenaga Kerja Asing) yang disahkan oleh Menteri atau pejabat yang ditunjuk, dan sedikitnya memuat:

a. alasan penggunaan TKA;

b. jabatan dan/atau kedudukan TKA dalam struktur organisasi perusahaan;

c. jangka waktu penggunaan TKA;

d. penunjukan tenaga kerja Indonesia sebagai pendamping TKA yang dipekerjakan.

Pasal 10 ayat (1) perpres ini, Pemberi Kerja TKA tidak wajib memiliki RPTKA untuk mempekerjakan TKA yang merupakan:

a. pemegang saham yang menjabat anggota Direksi atau anggota Dewan Komisaris pada Pemberi Kerja TKA;

b. pegawai diplomatik dan konsuler pada perwakilan negara asing; atau

c. TKA pada jenis pekerjaan yang dibutuhkan oleh pemerintah

Ditegaskan pula dalam Perpres ini, untuk pekerjaan yang bersifat darurat dan mendesak, menurut Perpres ini, Pemberi Kerja TKA dapat mempekerjakan TKA dengan mengajukan permohonan pengesahan RPTKA kepada Menteri atau pejabat yang ditunjuk paling lama 2 (dua) hari kerja setelah TKA bekerja. Selanjutnya, pengesahan RPTKA akan diberikan paling lama 1 (satu) hari kerja setelah permohonan diterima secara lengkap. Pemberi Kerja TKA yang akan mempekerjakan TKA menyampaikan data calon TKA kepada menteri atau pejabat yang ditunjuk, yang meliputi:

a. nama, jenis kelamin, tempat dan tanggal lahir;

b. kewarganegaraan, nomor paspor, masa berlaku paspor, dan tempat paspor diterbitkan;

c. nama, jabatan, dan jangka waktu bekerja;

d. pernyataan penjaminan dari pemberi kerja TKA; dan

e. ijazah pendidikan dan surat keterangan pengalaman kerja atau sertifikasi kompetensi sesuai dengan syarat jabatan yang akan diduduki TKA.

Menteri atau pejabat yang ditunjuk menyampaikan notifikasi penerimaan data calon TKA sebagaimana dimaksud kepada Pemberi Kerja TKA paling lambat 2 (dua) hari kerja dengan tembusan Direktorat Jenderal Imigrasi. Pemberi Kerja TKA wajib membayar dana kompensasi penggunaan TKA yang dipekerjakan setelah menerima notifikasi, dan dilakukan melalui bank yang ditunjuk oleh Menteri, yang merupakan Penerimaan Negara Bukan Pajak. Pembayaran dana kompensesi penggunaan TKA dan kewajiban memiliki RPTKA ini tidak diwajibkan bagi instansi pemerintah, perwakilan negara asing, dan badan internasional yang mempekerjakan TKA.

Dalam Pasal 20 ayat (1) Perpres ini ditegaskan, setiap TKA yang bekerja di Indonesia wajib memiliki Visa Tinggal Terbatas atau Vitas untuk bekerja, yang dimohonkan oleh Pemberi Kerja TKA atau TKA kepada menteri yang membidangi urusan pemerintahan di bidang hukum dan hak asasi manusia atau pejabat yang ditunjuk, dengan melampirkan notifikasi dan bukti pembayaran. Permohonan Vitas sebagaimana dimaksud sekaligus dapat dijadikan permohonan Izin Tinggal Sementara atau Itas. Izin Tinggal bagi TKA untuk pertama kali diberikan paling lama 2 (dua) tahun, dan dapat diperpanjang sesuai dengan ketentuan peraturan perundang- 
Website : http://yustisia.unmermadiun.ac.id/index.php/yustisia

undangan. Pemberian Itas bagi TKA sebagaimana dimaksud, menurut Perpres ini, sekaligus disertai dengan pemberian Izin Masuk Kembali untuk beberapa kali perjalanan yang masa berlakunya sesuai dengan dengan masa berlaku Itas. Setiap Pemberi Kerja TKA juga wajib menjamin TKA terdaftar dalam Jaminan Sosial Ketenagakerjaan bagi TKA yang bekerja lebih dari 6 (enam) bulan dan/atau polis asuransi di perusahaan asuransi berbadan hukum Indonesia.

Dari beberapa isi dalam Perpres yang penulis sebatukan diatas, mengisyaratkan bahwa dengan dikeluarkan Perpres ini bukan untuk memudahkan TKA untuk masuk ke Indoensia tapi untuk meningkatkan masuknya investasi ke Indonesia. Terkait dengan banyak masuknya TKA dari China menurut penulis, masyarakat tidak perlu merasa khawatir, karena jumlah TKA asal China yang tercatat di Indonesia melalui Kementerian Ketenagakerjaan (Kemnaker) Republik Indonesia hanya berjumlah 21 ribu dari keseluruhan TKA di Indonesia yang berada di kisaran angka 70 ribuan. Sedangkan terkait data yang tercatat di Keimigrasian dimana terdapat 31 ribu TKA China, semua itu lantaran imigrasi turut mencatat seluruh perlintasan para TKA China tersebut. $^{17}$

Filosofi dasar penggunaan TKA adalah sebagai serangkaian upaya untuk meningkatkan investasi, alih teknologi (Transfer of Technology) dan alih keahlian (Transfer of Skill) kepada TKI, serta perluasan kesempatan kerja. ${ }^{18}$ Oleh karena itu investasi asing di Indonesia sepenuhnya ditujukan untuk kesejahteraan masyarakat Indonesia. Hal ini sesuai dengan Konsideran Undang-Undang Nomot 13 Tahun 2003 tentang Ketenagakerjaan yaitu untuk memberikan perlindungan terhadap tenaga kerja dengan menjamin hak hak dasar pekerja/buruh, kesamaan kesempatan serta perlakuan non diskriminasi atas dasar apapun untuk mewujudkan kesejahteraan pekerja/buruh dan keluarganya dengan tetap memperhatikan perkembangan kemajuan dunia usaha.

Meningkatnya investasi pasti selaras dengan datangnya pekerja asing. Kondisi ini sebagai konsekuensi, karena TKA merupakan komponen kritis dari investasi, sehingga wajar jika negara investor mengirim orang mereka untuk menjamin keberhasilan investasi tersebut. Keberadaan investasi asing ini, merupakan bagian dari perjanjian perdagangan bebas yang dibuat pemerintahan sebelumnya. Ada beragam perjanjian yang mesti dipegang komitmennya oleh Indonesia baik dalam kerangka bilateral maupun regional, yaitu Indonesia-Jepang, ASEAN-China, ASEAN-FTA, ASEAN Korea, ASEAN-India atau ASEAN-Australia New Zealand. ${ }^{19}$ Saat ini, Indonesia terikat akan komitmen antar bangsa dan bilateral yang menyertakan berbagai regulasi keluar masuknya tenaga kerja. Dimana setiap negara dalam interaksi perdagangan barang dan jasa tidak boleh diskriminatif, terbuka, dan timbale balik melalui mekanisme _request and offer' ${ }^{20}$

Pelaksanaan penggunaan jasa TKA di Indonesia seharusnya berdasarkan pada prinsip-perinsip berikut: ${ }^{21}$

a. Legal, bahwa setiap pemberi kerja yang mempekerjakan TKA harus memiliki izin tertulis dari menteri atau pejabat yang ditunjuk (Pasal 42 Ayat (1) UU Nomor 13 Tahun 2003),

b. Sponsorship, bahwa pemberi kerja orang perorangan dilarang mempekerjakan TKA (Pasal 42 Ayat (2) UU Nomor 13 Tahun 2003),

c. Selective, bahwa TKA dipekerjakan dalam hubungan kerja untuk jabatan tertentu dan waktu tertentu (Pasal 42 Ayat (4) UU Nomor 13 Tahun 2003), dan

d. Security, bahwa penggunaan TKA harus sesuai dengan peraturan perundangan yang berlaku di Indonesia dan tidak membahayakan keamanan negara.

Dan didukung dengan adanya persyaratan dalam Peraturan Presiden Nomor 20 Tahun 2018 tentang Penggunaan Tenaga Kerja Asing seperti yang sudah penulis paparkan sebelumnya, maka pelaksanaan penggunaan TKA akan lebih optimal untuk meningkatkan investasi di Indonesia. Namun tentu saja kendala selalu ada di lapangan, dengan meningkatnya (tingginya) kedatangan TKA, maka meningkat pula potensi pelanggaran keimigrasian yang dilakukan oleh WNA seperti banyaknya fenomena TKA ilegal. Keberadaan pekerja asing ilegal itu merugikan masyarakat sebab mereka mengambil kesempatan kerja yang mestinya bisa menjadi hak warga Negara Indonesia seperti banyak ditemukan beberapa pekerja asal China yang mengerjakan pekerjaan kasar, pekerjaan yang tak membutuhkan keahlian khusus. Masalah lain juga muncul dengan adanya disparitas jumlah TKA antara Kemenkumham (Ditjen Imigrasi) dengan Kemenaker disebabkan oleh adanya perbedaan data yang digunakan, jika Ditjen Imigrasi berdasarkan data transaksional kedatangan orang asing (data perlintasan) sehingga jumlah orang asing yang masuk akan terus bertambah setiap saat, hal ini berbeda

\footnotetext{
${ }^{17}$ http://kemnaker.go.id/berita/beritanaker/menkumham-tegaskan-isu-serbuan-tkaChina-itu-hoax, (diakses 9 Oktober 2018, 09.30 WIB).

${ }^{18}$ Ahmadi Miru, 2008, Hukum Kontrak dan Perancangan Kontrak, Jakarta: PT. Rajagrafindo Persada,hlm. 35.

${ }^{19} \mathrm{http}: / /$ sorot.news.viva.co.id/news/read/867600-riuhpekerja-tirai-bambu, (diakses 9 Oktoberi 2018, 10.42.WIB).

${ }^{20} \mathrm{http} / / /$ kemnaker.go.id/berita/beritanaker/prinsippenggunaan-tenaga-kerja-asing-di indonesia, (diakses 9 Oktober 2018, 11.09 WIB).

${ }^{21}$ Ibid
} 
Website : http://yustisia.unmermadiun.ac.id/index.php/yustisia

dengan Kemenaker yang menggunakan data berdasarkan dokumen izin untuk bekerja (Izin Menggunakan TKA/IMTA).

Selain itu belum adanya sistem database terpadu (integrated database system) yang bisa diakses oleh pemangku kepentingan dan masyakat secara umum sehingga menimbulkan interpretasi yang berbeda terkait jumlah TKA di Indonesia. Untuk itu diperlukan sistem database terpadu terkait pengawasan orang asing agar tidak menimbulkan ketidakpastian di masyarakat dengan beberapa pertimbangan:

a. jika setiap orang asing yang harus melapor ke setiap instansi terkait, maka menyebabkan rasa tidak nyaman;

b. membutuhkan waktu yang lebih lama;

c. di negara-negara tertentu tidak ada kewajiban orang asing untuk melaporkan dirinya; dan

d. adanya klausul bahwa data orang asing dapat diberikan jika pihak imigrasi memintanya.

Untuk itu diperlukannya pengawasan dan pengendalian TKA untuk meminimalisisr adanya TKA illegal yang masuk ke Indonesia. Sebagaimana diketahui bahwa Kebijakan keimigrasian terhadap orang asing yang berlaku di Indonesia melalui 2 (dua) pendekatan prosperiti yaitu orang asing yang diizinkan masuk, berada dan melakukan kegiatan di wilayah Indonesia hanya yang benar-benar menguntungkan bagikemakmuran dan kesejahteraan rakyat Indonesia, selain itu melalui pendekatan sekuriti yakni mengizinkan memberikan perizinan keimigrasian hanyalah terhadap mereka yang tidak akan membahayakan keamanan negara dan ketertiban umum. ${ }^{22}$ Hal ini sejalan dengan prinsip yang bersifat selektif (selective policy) dari keimigrasian sehingga dapat meminimalisir timbulnya pengaruh negative bagi negara dan masyarakat Indonesia yang dapat merugikan perekonomian bangsa Indonesia, bahkan mungkin saja dapat menimbulkan ketidakstabilan keamanan dan ketertiban karena orang asing tersebut dapat melakukan tindak pidana terhadap Warga Negara Indonesia. Untuk mewujudkan prinsip selektif, diperlukan pengawasan yang komprehensip terhadap orang asing pada saat orang asing masuk ke wilayah Indonesia. Pelaksanaan pengawasan terhadap WNA di Indonesia meliputi 2 (dua) hal pokok yaitu pengawasan terhadap keberadaannya (secara immigratoir) dan pengawasan terhadap kegiatan orang asing selama berada di Indonesia. ${ }^{23}$

Untuk menindaklanjuti pengawasan terhadap TKA di Indonesia, maka dilakukan mekanisme pengawasan dalam bentuk:

a. pengawasan preventif-edukatif yang mencakup sosialisasi, bimbingan teknis pelaksanaan aturan penggunaan TKA, dan pembinaan kepada perusahaan pengguna TKA.

b. pengawasan persuasif non-justisia. Ini mencakup pemeriksaan atas pelanggaran penggunaan TKA, baik secara pro-aktif maupun responsif berdasarkan laporan dari masyarakat.

c. pengawasan represif pro-justisia. Ini mencakup penyelidikan dan penyidikan atas pelanggaran aturan penggunaan TKA. Dalam hal ini pengawasan itu bisa dilakukan secara berkala, khusus, insidentil, dan juga responsif. $^{24}$

\section{KESIMPULAN}

Berdasarkan pembahasan yang penulis jabarkan terkait penggunaan TKA diIndonesia saat ini yang didukung dengan dikeluarkannya Peraturan Presiden (Perpres) Nomor 20 Tahun 2018 tentang Penggunaan Tenaga Kerja Asing (TKA), menurut penulis akan berdampak baik untuk perkembangan investasi dari luar negeri ke Indonesia. Karena pada dasarnya Perpres ini bertujuan untuk mempermudah prosedur penggunaan TKA untuk meningkatkan investasi, bukan untuk mempermudah persyaratan TKA masuk ke Indonesia. Semakin banyak investor atau pemodal yang berinvestasi di Indonesia maka semakin banyak pula lapangan kerja baru yang bisa dibuka. Melalui perpres tersebut, pemerintah ingin menerapkan kemudahan pemberian visa bagi tenaga ahli asing guna proses transfer pengetahuan dan teknologi bagi tenaga kerja lokal. Namun tentu saja pemerintah tetap harus secara ketat menyeleksi TKA yang masuk ke Indonesia dan mengoptimalkan pengawasan dan pengendalian terhadap masuknya WNA si Indonesia terkait dengan banyaknya TKA illegal yang masuk di Indonesia.

\footnotetext{
${ }^{22}$ Wahyudin Ukun, Deportasi Sebagai Instrumen Penegakan Hukum dan Kedaulatan Negara di Bidang Keimigrasian, (Jakarta: PT. Adi Kencana Aji, 2004), hlm. 18. - lihat juga http://digilib.unila.ac.id115094-BAB-II.pdf, (diakses 11 Oktober 2018, 12.15 WIB).

${ }^{23}$ Sihar Sihombing, 2013, Hukum Keimigrasian Dalam Hukum Indonesia, Bandung: Nuansa Aulia, hal.23.

${ }^{24} \mathrm{http}$ ///kemnaker.go.id/berita/beritakemnaker/mekanisme-pengendalian-danpengawasan penggunaan-tka-olehpengawasketenagakerjaan, (diakses 19 Oktoberi 2018, 09.25 WIB).

Volume 4 Nomor 2 September 2018, YUSTISIA MERDEKA | 154
} 


\section{Website : http://yustisia.unmermadiun.ac.id/index.php/yustisia}

\section{DAFTAR PUSTAKA}

Agusmidah, 2011, Dilematika Hukum Ketenagakerjaan, Tinjauan Politik Hukum, buku II, Jakarta: PT.Sofmedia. Abdul Khakim, 2009, Dasar-Dasar Hukum Ketenagakerjaan Indonesia, Bandung: Citra Aditya Bakti.

Ahmadi Miru, 2008, Hukum Kontrak dan Perancangan Kontrak, Jakarta: PT. Rajagrafindo Persada.

HR Abdussalam, 2008, Hukum Ketenagakerjaan, Jakarta : Restu Agung.

Imam Soepomo dalam Zaeny Asyhadie, 2013, Hukum Ketenagakerjaan Bidang Hubungan Kerja, Jakarta: Raja Grafindo Persada. Rony Hanintyo Soemitro, 1982, Metodologi Penelitian Hukum, Ghalia Indonesia, Jakarta.

Suhandi. Pengaturan Ketenagakerjaan Terhadap Tenaga Kerja Asing Dalam Pelaksanaan Masyarakat Ekonomi Asean Di Indonesia, Jurnal Fakultas Hukum Universitas Wijaya Kusuma Surabaya, Perspektif Volume XXI No. 2 Tahun 2016 Edisi Mei.

Siti Rahmawati dan Ni Luh Gede Astariyani, , 2016, Akibat Hukum Terhadap Penggunaan Tenaga Kerja Asing Ilegal menurut UndangUndang Nomor 13 Tahun 2003 Tentang Ketenagakerjaan, Karya Ilmiah, Fakultas Hukum Universitas Udayana.

Sihar Sihombing, 2013, Hukum Keimigrasian Dalam Hukum Indonesia, Bandung: Nuansa Aulia.

Sri Badi Purwaningsih, 2005, "Pembatasan Penggunaan Tenaga Kerja Asing Pada Perusahaan-Perusahaan PMA di Jawa Tengah", Tesis Magister Hukum, Semarang: Universitas Diponegoro.

Peter Mahmud Marzuki, 2007,Penelitian Hukum, Kencana Prenada Media Group, Jakarta.

Wahyudin Ukun, 2004, Deportasi Sebagai Instrumen Penegakan Hukum dan Kedaulatan Negara di Bidang Keimigrasian, Jakarta: PT. Adi Kencana Aji.

http://businesslaw.binus.ac.id/2017/01/29/tenaga-kerja-asing/diakses tanggal 18 Oktober 2018 Pukul 18.35 WIB.

http://kemnaker.go.id/berita/beritanaker/menkumham-tegaskan-isu-serbuan-tkaChina-itu-hoax, (diakses 9 Oktober $2018,09.30$ WIB. http://sorot.news.viva.co.id/news/read/867600-riuhpekerja-tirai-bambu, (diakses 9 Oktoberi 2018, 10.42.WIB.

http://kemnaker.go.id/berita/beritanaker/prinsippenggunaan-tenaga-kerja-asing-di indonesia, (diakses 9 Oktober 2018, 11.09 WIB. http://digilib.unila.ac.id115094-BAB-II.pdf, (diakses 11 Oktober 2018, 12.15 WIB.

http://kemnaker.go.id/berita/berita kemnaker mekanisme-pengendalian dan pengawasan penggunaan-tka-oleh pengawas ketenagakerjaan, (diakses 19 Oktoberi 2018, 09.25 WIB.

Undang-Undang Nomor 13 Tahun 2003 tentang Ketenagakerjaan

Peraturan Presiden Nomor 20 Tahun 2018 tentang Penggunaan Tenaga Kerja Asing 